\title{
Stress Distribution Analysis of DKDT Tubular Joint in a Minimum Offshore Structure
}

\author{
Irma Noviyanti ${ }^{1}$, Rudi Walujo Prastianto ${ }^{1 \star}$, Murdjito ${ }^{1}$ \\ ${ }^{1}$ Department of Ocean Engineering, Institut Teknologi Sepuluh Nopember \\ Jl. Kampus ITS Keputih Sukolilo 60111 Surabaya \\ *rudiwp@oe.its.ac.id \\ DOI: https://doi.org/10.21107/rekayasa.v14i2.10511
}

\begin{abstract}
A marginal field defines as an oil and/or gas field that has a short production period, low proven reservoir, and could not be exploited using existing technology. As the demand for oil and gas keeps increasing, one of the solutions to tackle the issues is to build the modified platform which came to be more minimalist to conduct the oil and gas production in the marginal field. Naturally, the minimum offshore structures are cost less but low in redundancy, therefore, pose more risks. Although the study on the minimum structures is still uncommon, there are opportunities to find innovative systems that need to have a further analysis toward such invention. Therefore, this study took the modified jacket platform as a minimum structure, and local stresses analysis by using finite element method is applied for the most critical tubular joint with multiplanarity of the joint is taking into account. The analysis was carried out using the finite element program of Salome Meca with three-dimensional solid elements are used to model the multiplanar joint. Various loading types of axial force, in-plane bending moment, and outof-plane bending moment are applied respectively to investigate the stress distribution along the brace-chord intersection line of the tubular joint. The results show that the hotspot stress occurred at a different point along each brace-chord intersection line for each loading type. Finally, as compared to the in-plane bending moment or out-of-plane bending moment loading types, the axial force loading state is thought to generate greater hotspot stress.
\end{abstract}

Keywords : multiplanar tubular joint, finite element analysis, local stress distribution, minimum offshore platform

\section{INTRODUCTION}

A production platform is one of the supporting facilities during the exploration and production phase of oil and gas. This type of platform is often designed to also operate as a wellhead platform, enabling the lifting of crude oil and the production process to take place in the same location. As time goes by, a lot of inventions have been carried out to satisfy the oil and gas demands that increasing every day. In recent days, the exploration of oil and gas is slowly conducted in a difficult area because of the reduction in oil and gas reserves at the conventional fields. According to annual report by SKK Migas, the working area of oil and gas in Indonesia dependent on conventional fields is decreasing averagely by 14,5 percent between 2014-2019, and is steadily shifting to operate in non-conventional fields (SKK Migas, 2019). This non-conventional area, which is often referred as a

\section{Article History:}

Received: April, 27 ${ }^{\text {th }}$ 2021; Accepted: July, $27^{\text {th }} 2021$

Rekayasa ISSN: 2502-5325 has been Accredited by Ristekdikti (Arjuna) Decree: No. 23/E/KPT/2019 August 8th, 2019 effective until 2023 marginal field, has the characteristics of low proven reserves, short production period, and hardly explored by using existing technology. To adapt with this condition, researchers have invented a modified platform such as in jacket, which could perform in unusual environment condition that the marginal field is having. The major difference in the modified jacket platform is in the configuration, which has been adjusted adequately.

A study about modification jackets has been conducted in 2012 which discussing about minimum facilities platforms (MFPs) with low cost (Nicholson \& Helle, 2013). The study also explains contractors' interest in developing marginal oil and gas fields is increasing every day. Therefore, a jacket with a minimum configuration as in MFPs is required. The MFPs are wellhead structure, which does not include any processing unit in its

\section{Cite this as:}

Noviyanti, I., Prastianto, W.P \& Murdjito. (2021). Stess Distribution Analysis of DKDT Tubular Joint in a Minimum Offshore Structure. Rekayasa 14 (2). 191-199. doi: https://doi.org/10.21107/rekayasa.v14i2.10511.

(C) 2021 Irma Noviyanti 
construction that makes the topside structure, has lighter weight. This form of platform also has many advantages over conventional jackets, including a shorter fabrication and installation time and a simpler installation process. CoSMOS (Conductor Assisted Minimal Offshore Structures) is an example of MFPs that uses a conductor as the main topside support. Clamps to maintain the structure's strength secure the conductor. Along with that, some aspects between CoSMOS and conventional jacket platform were being compared. In terms of cost, the CoSMOS platform is estimated to save up to $\$ 7,7$ million compared to a conventional jacket and to take half a year faster in fabrication and installation process. Besides the cost and time aspect, the fatigue life of a minimum jacket had also been studied and examined by comparing it to the fatigue life of a conventional jacket (Giffary, 2020).

The analysis begins with the assessment of both structures' natural periods and response amplitude operator (RAO) which used as the transfer function to obtain the responses of the structure under environmental loads. Calculation of fatigue life is taken place in the main joints, which links up the major elements such as jacket leg with braces. Efthymiou formula will be used to calculate the SCF value using the stresses obtained from the global analysis. The results of the analysis shows that the minimum jacket platform has a shorter fatigue life than the conventional jacket.

While cost is one of the important factor in the construction of MFPs, the structure's strength must also be considered, particularly in the tubular joint region. This is because the tubular joint is exposed to loads from current environmental conditions during its service life. To attain a more accurate deformation of the tubular joint when subjected to a particular load, a local analysis is often needed. The finite element method is a common method used in the local analysis in general. The basic principle of this method is to divide a structure into the smaller element (discretization) to obtain the stress and deformation at every element. Hence, this method will provide a more precise result than the global analysis did. Nonetheless, a global analysis is still needed before a local analysis is conducted to determine which joint would be the most critical and therefore should be examined further (Mirtaheri et al., 2009). To obtain the maximum load that the tubular joint could withstand, the method of applying remote loading could be an option (Chandran \& S, 2016). The procedure is to apply loads that change by the time until the structure reaches maximum deformation. In this study, tubular K-type joint is being analyzed. There are four cases of loading type to be applied in the analysis, which are tension force, compression force, in-plane bending moment, and out-plane bending moment.

The analysis is performed with the aim of obtaining the maximum stress and deformation of the brace. Furthermore, the objective of the local analysis is not only to determine the tubular joint's stress and deformation. By assessing the stress concentration factor (SCF), the stress result may be used to calculate the fatigue life of the entire structure. However, tubular joint analysis is generally accomplished in a uniplanar type of joint. That was most definitely, because the existing SCF formula is restricted to a uniplanar tubular joint. Multiplanarity in the tubular joint also has influences such as in the hotspot stresses, which later affects the SCF as well, as investigated in previous studies with various type of multiplanar tubular joint and their mode of loadings ( $R$. Prastianto et al., 2020; R. W. Prastianto, Hadiwidodo, \& Fuadi, 2018; R. W. Prastianto, Hadiwidodo, Fuadi, et al., 2018).

It is obvious that a minimum jacket is such an innovation in the oil and gas industry that a followup study focusing on the minimum jacket platform became necessary. The existing codes and standar only provides the calculation formula of a platform in the general form. Under those conditions, minimum jacket will be an object of analysis in this study with the objective to obtain hotspot stress of a tubular joint by performing local analysis. The analysis will be conducted by finite element method with the aim to extract the stress distribution along the weld toe between chord and braces. The stresses from the weld toe is considered as the hotspot stress of the tubular joint, which later is used to quantifying the value of the SCF. The analysis will be conducted in three form with each different loading conditions, which are axial force, in-plane bending moment, and out-of-plane bending moment.

\section{RESEARCH METHODS \\ Material Properties and Loading Condition}

The jacket platform used as the object of this study is a three-legged wellhead platform with three levels of topside and designed to operate in a water depth of $61 \mathrm{~m}$ as shown in Figure 1. All the 
material properties and environmental data needed for the global analysis were attained from the previous study which has the same analysis object (Giffary, 2020). Performing global analysis is compulsory in order to obtain the loading condition of the tubular joint. Henceforth, the tubular joint, which resists the greatest loads, will be taken to have a further analysis.

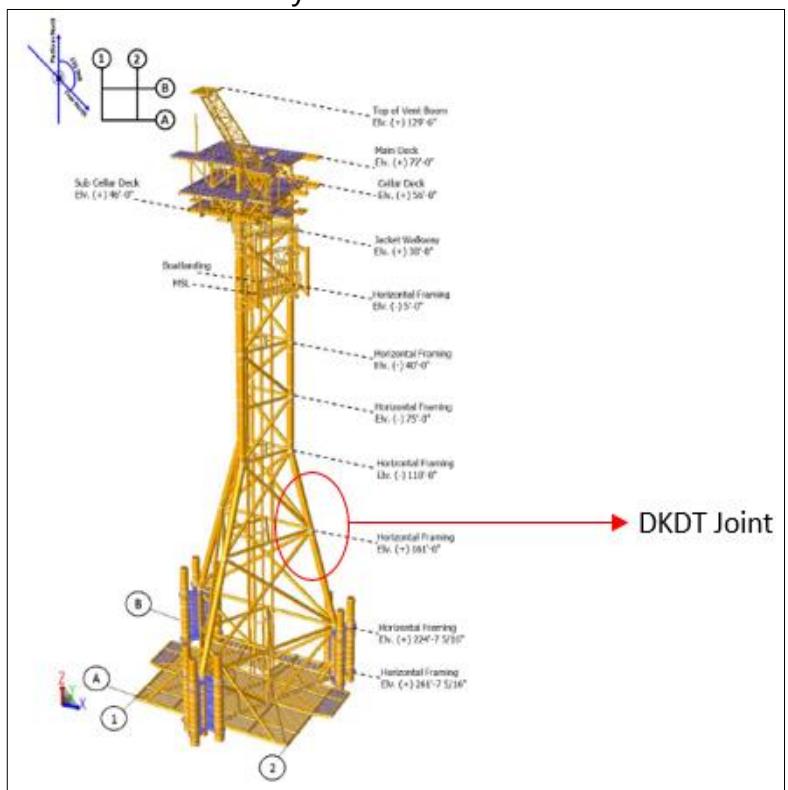

Figure 1. Three-Legged Minimum Jacket Platform

According to the global analysis, the tubular joint which carrying the maximum loads is in DKDT (Double $\mathrm{K}$ and Double $\mathrm{T}$ ) form and the material properties of the tubular joint is written in Table 1. The performed global analysis taken in this study is a static in-place analysis and the equation is referring to international codes (API, 2007).

Table 1. Material Properties of the Tubular Joint

\begin{tabular}{ccccc}
\hline Member & $\begin{array}{c}\text { Length } \\
\text { (ft) }\end{array}$ & $\begin{array}{c}\text { Mod. } \\
\text { Young } \\
\text { (ksi) }\end{array}$ & $\begin{array}{c}\text { Outside } \\
\text { Diameter } \\
\text { (in) }\end{array}$ & $\begin{array}{c}\text { Wall } \\
\text { Thickness } \\
\text { (in) }\end{array}$ \\
\hline Middle & 13.583 & 29000 & 54 & 2.5 \\
Chord & & & & 2.5 \\
Chord 1 & 38.318 & 29000 & 53 & 2.5 \\
Chord 2 & 52.503 & 29000 & 53 & 0.75 \\
Brace 1 & 23.476 & 29000 & 24 & 0.75 \\
Brace 2 & 29.232 & 29000 & 24 & 1.375 \\
Brace 3 & 43.006 & 29000 & 30 & 1.25 \\
Brace 4 & 43.203 & 29000 & 28 & 1.25 \\
Brace 5 & 45.444 & 29000 & 28 & 1.25 \\
Brace 6 & 40.205 & 29000 & 28 & \\
\hline
\end{tabular}

Later on, the local analysis will be performed in three conditions with three different loading types which are axial force, in-plane bending moment (IPB), and out-of-plane bending moment (OPB). The loading of each condition is written in Table 2.
Table 2. Loading Condition Subjected To the Tubular Joint

\begin{tabular}{cccc}
\hline Brace & $\begin{array}{c}\text { Axial Force } \\
\mathbf{( k N )}\end{array}$ & IPB (kN.m) & OPB (kN.m) \\
\hline Brace 1 & 223.081 & -109.386 & 0.0193233 \\
Brace 2 & 340.656 & -38.844 & 0.0132334 \\
Brace 3 & -1049.596 & 84.107 & 0.0132334 \\
Brace 4 & 221.542 & -109.386 & 0.2343343 \\
Brace 5 & -586.596 & 101.176 & 0.3423423 \\
Brace 6 & -106.988 & -102.503 & 0.3423443 \\
\hline
\end{tabular}

\section{Structural Modelling}

The tubular joint is modelled in Salome Meca by using the Geometry module (Aubry, 2013). The welding area at the intersection between tubular members is as well being modelled (AWS, 1981). A 3-D solid element is taken as the element type of the model because it is considered to generate more accurate stress result with lower margin error (Ahmadi \& Ziaei Nejad, 2017). Modelling result of tubular joint is displayed in Figure 2.

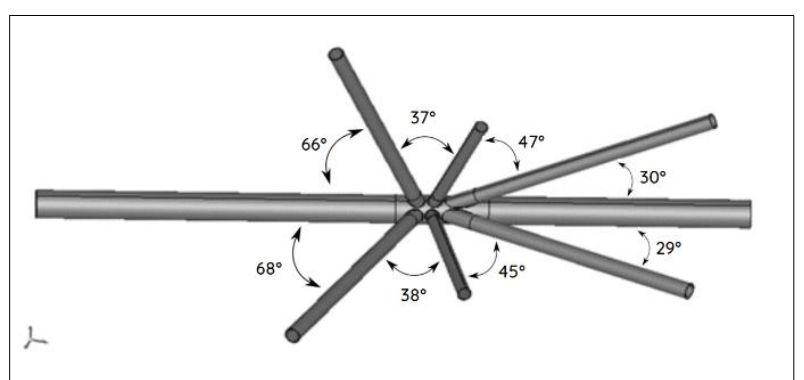

Figure 2. Tubular Joint Model and Detail Modelling of Welding Area

\section{Finite Element Method Analysis}

The stress distribution along the weld toe between chord and braces is determined using finite element analysis. Salome Meca is open-source software that is used to run the analysis using the Aster Study module with the CALC CHAMP operation (Sellenet, 2016). The weld toe at the chord and brace sides is used as the object reference for the stress distribution as Figure 3.

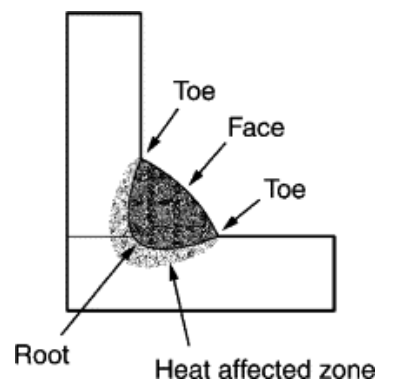

Figure 3. Object Reference of the Weld Toe 
Furthermore, as shown in Figure 4, the area along the weld toe is divided into four regions which are upper saddle, lower saddle, crown toe, and crown heel.

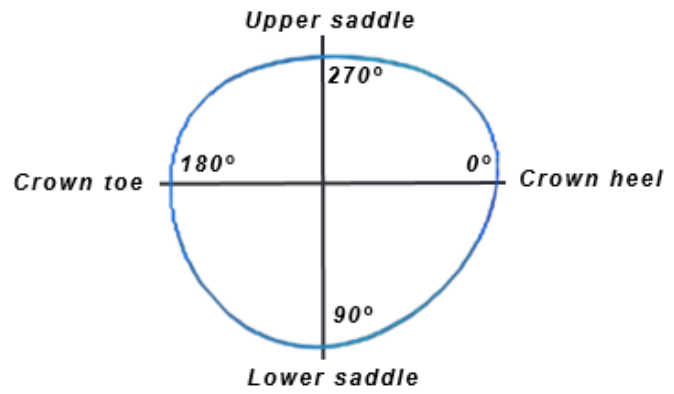

Figure 4. Regions Along The Weld Toe

\section{RESULTS AND DISCUSSION Meshing Sensitivity Analysis}

The objective in performing meshing sensitivity analysis is to validate the model as well as the amount of meshing element or size that the model having in order to have further analysis afterward. The procedure of the analysis is to applying boundary conditions into the model and divide the structure into smaller elements. The boundary condition of the support at the end of each chord of the tubular joint is varying from almost pinned to almost fixed. Hence, in general, the fixed support could be used in the analysis (Sellenet, 2016). Along with that, the loading condition of combination load, which consists of axial force, in-plane bending moment, and out-of-plane bending moment, is subjected to the braces. Table 3

Table 3 is showing the stress results due to number of elements taken in every analysis.

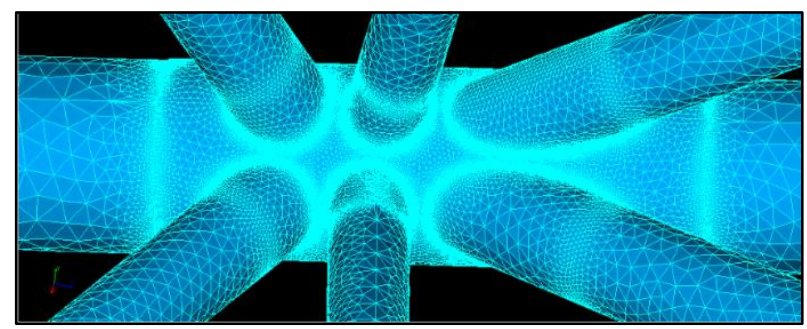

Figure 5. Reference Node For Meshing Sensitivity Analysis

The stresses are taking place at the same location as shown in Figure 5. Subsequently, the number of errors between one analysis and afterward is also calculated to justify the consistency of the stress result as reported in Table 3

Table 3. Additionally, stress result from Table 3 is visualized in a diagram as shown in Figure 6. It is shows that the diagram is forming a stationery line between the numbers of elements by 394937 to 801149. Therefore, the model which carrying those number of element range is considered stable. In conclusion, 574247 elements with $0.07 \%$ error is taken to perform the next analysis.

Table 3. Stress Result of Meshing Sensitivity Analysis

\begin{tabular}{cccccc}
\hline $\begin{array}{c}\text { Number } \\
\text { of } \\
\text { Element }\end{array}$ & \multicolumn{3}{c}{ Stress Probe } & Stress & Error \\
\cline { 2 - 4 }$(\mathbf{m})$ & $\mathbf{Y}$ & $\mathbf{( m )}$ & $\mathbf{Z}(\mathbf{m})$ & $(\mathbf{M P a})$ & $(\mathbf{\% )}$ \\
\hline 255955 & 9.055 & 9.535 & -48.63 & 14.12 & \\
256191 & 9.055 & 9.535 & -48.63 & 14.63 & 3.51 \\
265270 & 9.055 & 9.535 & -48.63 & 23.14 & 36.75 \\
283171 & 9.055 & 9.535 & -48.63 & 22.81 & 1.44 \\
331093 & 9.055 & 9.535 & -48.63 & 20.94 & 8.17 \\
394937 & 9.055 & 9.535 & -48.63 & 21.40 & 2.19 \\
459861 & 9.055 & 9.535 & -48.63 & 21.32 & 0.35 \\
574247 & 9.055 & 9.535 & -48.63 & 21.31 & 0.07 \\
707153 & 9.055 & 9.535 & -48.63 & 21.54 & 1.06 \\
801149 & 9.055 & 9.535 & -48.63 & 21.47 & 0.33 \\
\hline
\end{tabular}

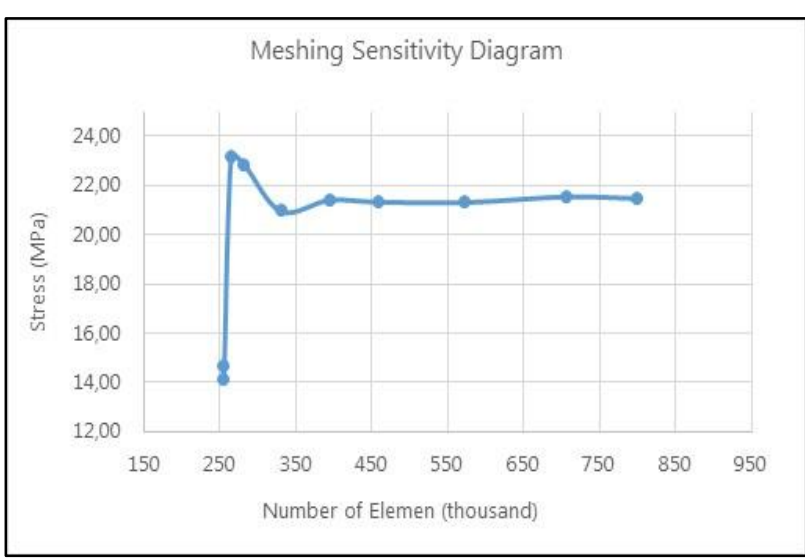

Figure 6. Meshing Sensitivity Analysis Diagram

\section{Local Stress Analysis Subjected to Axial Force Loading}

The boundary condition of the analysis is presented in Figure 7.

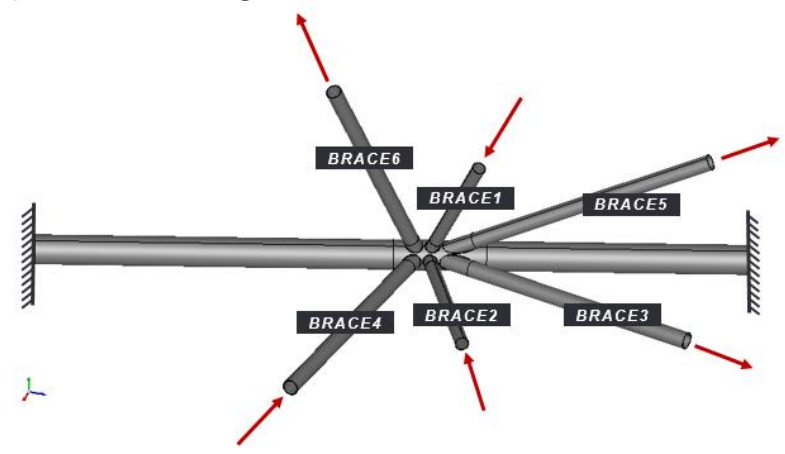

Figure 7. Boundary Condition in The Local Stress Analysis Subjected to Axial Force Loading

The fixity or support at the end of each chord is taken to be fixed and the loading condition is referring to Table 2. Directions of the axial forces also referring to Table 2 which the negative axial force is deemed to be tension force and otherwise, 
Table 4. Stresses Along Weld Toe of The Chord's Side Subjected to Axial Force Loading

\begin{tabular}{ccccccc}
\hline \multirow{2}{*}{ Angle (deg) } & Brace 3 & Brace 5 & Brace 2 & Brace 1 & Brace 4 & Brace 6 \\
\cline { 2 - 7 } & $\mathbf{( M P a )}$ & $\mathbf{( M P a )}$ & $\mathbf{( M P a )}$ & $\mathbf{( M P a )}$ & $\mathbf{( M P a )}$ & $\mathbf{( M P a )}$ \\
\hline 0 & $4.68 \mathrm{E}+00$ & $3.80 \mathrm{E}+00$ & $1.28 \mathrm{E}+01$ & $1.32 \mathrm{E}+01$ & $4.79 \mathrm{E}+00$ & $1.69 \mathrm{E}+01$ \\
22.5 & $8.90 \mathrm{E}+00$ & $4.74 \mathrm{E}+00$ & $1.35 \mathrm{E}+01$ & $1.26 \mathrm{E}+01$ & $8.24 \mathrm{E}+00$ & $1.80 \mathrm{E}+01$ \\
45 & $1.01 \mathrm{E}+01$ & $4.44 \mathrm{E}+00$ & $1.25 \mathrm{E}+01$ & $1.71 \mathrm{E}+01$ & $1.26 \mathrm{E}+01$ & $1.76 \mathrm{E}+01$ \\
67.5 & $8.17 \mathrm{E}+00$ & $7.44 \mathrm{E}+00$ & $1.28 \mathrm{E}+01$ & $1.74 \mathrm{E}+01$ & $1.11 \mathrm{E}+01$ & $1.50 \mathrm{E}+01$ \\
90 & $9.26 \mathrm{E}+00$ & $9.03 \mathrm{E}+00$ & $1.39 \mathrm{E}+01$ & $1.63 \mathrm{E}+01$ & $7.24 \mathrm{E}+00$ & $1.74 \mathrm{E}+01$ \\
112.5 & $9.48 \mathrm{E}+00$ & $1.08 \mathrm{E}+01$ & $1.36 \mathrm{E}+01$ & $1.53 \mathrm{E}+01$ & $4.86 \mathrm{E}+00$ & $1.66 \mathrm{E}+01$ \\
135 & $1.11 \mathrm{E}+01$ & $1.54 \mathrm{E}+01$ & $1.11 \mathrm{E}+01$ & $1.65 \mathrm{E}+01$ & $3.85 \mathrm{E}+00$ & $1.53 \mathrm{E}+01$ \\
157.5 & $1.89 \mathrm{E}+01$ & $2.21 \mathrm{E}+01$ & $8.92 \mathrm{E}+00$ & $1.58 \mathrm{E}+01$ & $4.77 \mathrm{E}+00$ & $1.06 \mathrm{E}+01$ \\
180 & $2.56 \mathrm{E}+01$ & $2.07 \mathrm{E}+01$ & $7.76 \mathrm{E}+00$ & $1.33 \mathrm{E}+01$ & $4.28 \mathrm{E}+00$ & $9.97 \mathrm{E}+00$ \\
202.5 & $2.98 \mathrm{E}+01$ & $1.37 \mathrm{E}+01$ & $1.49 \mathrm{E}+01$ & $1.33 \mathrm{E}+01$ & $1.02 \mathrm{E}+01$ & $1.54 \mathrm{E}+01$ \\
225 & $2.24 \mathrm{E}+01$ & $7.70 \mathrm{E}+00$ & $1.87 \mathrm{E}+01$ & $1.46 \mathrm{E}+01$ & $1.39 \mathrm{E}+01$ & $1.73 \mathrm{E}+01$ \\
247.5 & $1.68 \mathrm{E}+01$ & $5.69 \mathrm{E}+00$ & $1.90 \mathrm{E}+01$ & $1.39 \mathrm{E}+01$ & $1.36 \mathrm{E}+01$ & $1.97 \mathrm{E}+01$ \\
270 & $1.17 \mathrm{E}+01$ & $4.36 \mathrm{E}+00$ & $1.70 \mathrm{E}+01$ & $1.14 \mathrm{E}+01$ & $1.38 \mathrm{E}+01$ & $2.16 \mathrm{E}+01$ \\
292.5 & $9.44 \mathrm{E}+00$ & $4.26 \mathrm{E}+00$ & $1.94 \mathrm{E}+01$ & $1.22 \mathrm{E}+01$ & $1.48 \mathrm{E}+01$ & $1.06 \mathrm{E}+01$ \\
315 & $8.85 \mathrm{E}+00$ & $4.18 \mathrm{E}+00$ & $1.59 \mathrm{E}+01$ & $1.45 \mathrm{E}+01$ & $1.60 \mathrm{E}+01$ & $1.00 \mathrm{E}+01$ \\
337.5 & $9.24 \mathrm{E}+00$ & $5.11 \mathrm{E}+00$ & $1.17 \mathrm{E}+01$ & $1.60 \mathrm{E}+01$ & $1.25 \mathrm{E}+01$ & $1.28 \mathrm{E}+01$ \\
360 & $4.78 \mathrm{E}+00$ & $4.88 \mathrm{E}+00$ & $1.29 \mathrm{E}+01$ & $1.32 \mathrm{E}+01$ & $4.79 \mathrm{E}+00$ & $1.64 \mathrm{E}+01$ \\
\hline
\end{tabular}

Table 5. Stresses Along Weld Toe of The Brace's Side Subjected to Axial Force Loading

\begin{tabular}{ccccccc}
\hline \multirow{2}{*}{ Angle (deg) } & Brace 3 & Brace 5 & Brace 2 & Brace 1 & Brace 4 & Brace 6 \\
\cline { 2 - 7 } & $\mathbf{( M P a )}$ & $\mathbf{( M P a )}$ & $\mathbf{( M P a )}$ & $\mathbf{( M P a )}$ & $\mathbf{( M P a )}$ & $\mathbf{( M P a )}$ \\
\hline 0 & 18.15 & 11.98 & 11.75 & 8.26 & 7.13 & 10.25 \\
22.5 & 16.99 & 10.32 & 9.89 & 9.33 & 10.75 & 9.26 \\
45 & 15.29 & 8.12 & 10.43 & 11.74 & 10.65 & 11.40 \\
67.5 & 12.06 & 6.09 & 10.74 & 12.21 & 7.01 & 10.64 \\
90 & 10.55 & 6.97 & 12.78 & 11.68 & 4.63 & 9.67 \\
112.5 & 9.79 & 8.93 & 11.13 & 11.19 & 3.95 & 9.78 \\
135 & 10.86 & 10.63 & 9.88 & 10.98 & 3.28 & 8.23 \\
157.5 & 17.39 & 19.85 & 13.75 & 9.97 & 2.07 & 6.33 \\
180 & 27.25 & 22.19 & 10.03 & 9.82 & 5.03 & 4.74 \\
202.5 & 25.61 & 14.91 & 12.26 & 10.11 & 9.07 & 7.36 \\
225 & 22.36 & 9.07 & 14.29 & 10.93 & 10.81 & 9.24 \\
247.5 & 14.36 & 6.95 & 14.97 & 10.60 & 14.38 & 10.71 \\
270 & 11.84 & 6.33 & 13.81 & 11.67 & 17.01 & 11.08 \\
292.5 & 11.54 & 6.58 & 12.31 & 11.85 & 13.31 & 15.18 \\
315 & 11.73 & 8.35 & 10.57 & 12.07 & 7.41 & 16.05 \\
337.5 & 14.35 & 11.29 & 12.23 & 9.96 & 4.64 & 11.21 \\
360 & 18.15 & 12.00 & 11.75 & 8.79 & 7.42 & 10.25 \\
\hline
\end{tabular}

the positive axial force is deemed to be compression force. After the analysis is performed, the stress result could be acquired. The stress result along the weld toe of the chord's side is reported in The point of reference taken in attaining the stress result along the weld toe took the interval of 22,5 degrees. Furthermore, the stress distribution is also displayed in Figure 8. It is shown from the diagram that Brace 3 is having the greatest stress amongst other braces. Furthermore, the stress distribution is reaching its peak at crown toe with magnitude of $29,8 \mathrm{MPa}$. The stress result of the analysis is also taking place along the weld toe of the brace's side as written in Table 5. Additionally, the result from Table $\mathrm{x}$ is presented as a diagram in Figure 9.

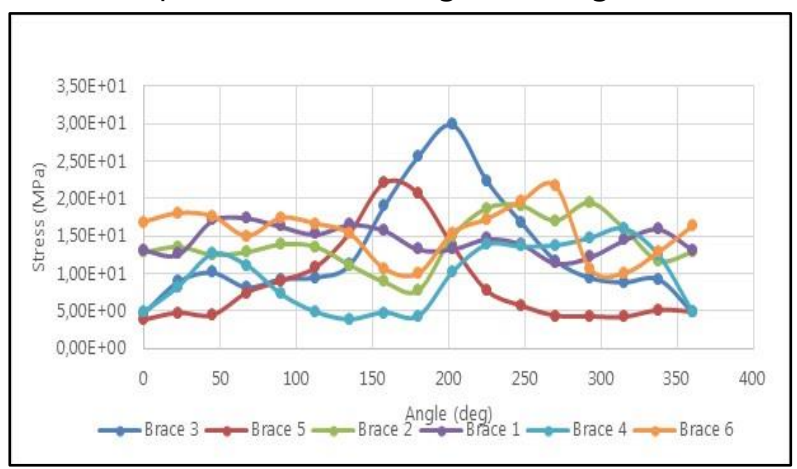

Figure 8. Stress Result Diagram Along Weld Toe of The Chord's Side Subjected to Axial Force Loading 


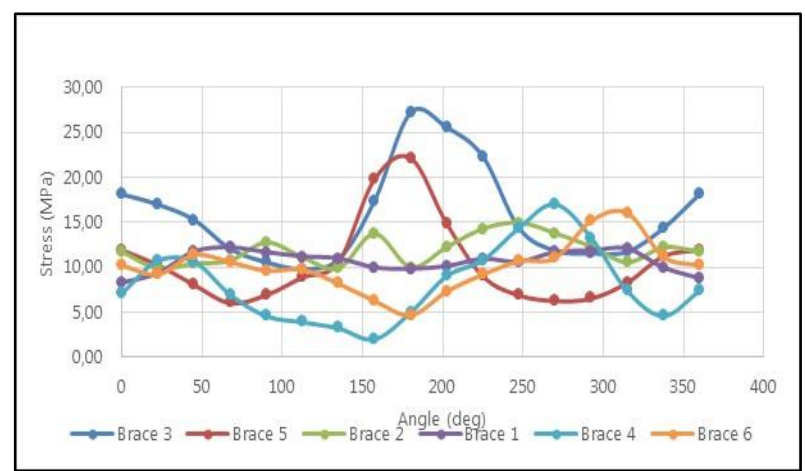

Figure 9. Stress Result Diagram Along Weld Toe of The Brace's Side Subjected to Axial Force Loading

Figure 9 shows that when tubular joint is subjected to axial force loading, the hotspot stress in the weld toe by the brace's side is occurring in Brace 3 at value of $27.25 \mathrm{MPa}$. From the conducted analysis result above, the value of hotspot stress and its occurring location could be concluded. In the area along the weld toe of the chord's side, the hotspot stress is occurring in Brace 3 at the crown toe with the value of $29.8 \mathrm{MPa}$. Following this, for the area along the weld toe of the brace's side, the hotspot stress is occurring in Brace 3 at crown toe with the value of $27.25 \mathrm{MPa}$.

\section{Local Stress Analysis Subjected to In-Plane Bending Moment Loading}

Figure 10 represents the boundary condition applied for the analysis. The value of in-plane bending moment subjected to the braces is referring to Table 2 and the end-support of each chord is presumed to be fixed.

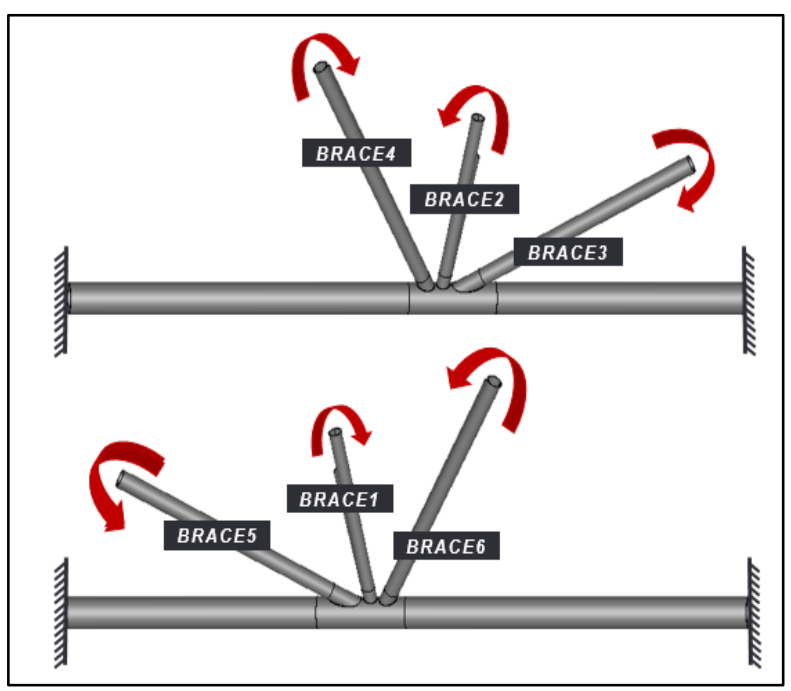

Figure 10. Boundary Condition in The Local Stress Analysis Subjected to In-Plane Bending Moment Loading
Directions of the in-plane bending moment is referring Table 2, which the positive in-plane bending moment is considered in a counterclockwise direction, and the negative in-plane bending moment is considered in a clockwise direction. The stress result is obtained after the analysis is completed. Table 6 shows the stress result along the weld toe of the chord's side. The interval of 22.5 degrees is being used as a point of reference in acquiring the stress result along the weld toe. The stress distribution from Table 6 also represented in form of diagram on Figure 11.

Table 6. Stresses along Weld Toe of The Chord's Side Subjected to In-Plane Bending Moment Loading

\begin{tabular}{ccccccc}
\hline $\begin{array}{c}\text { Angle } \\
\text { (deg) }\end{array}$ & $\begin{array}{c}\text { Brace } \\
\mathbf{3}\end{array}$ & $\begin{array}{c}\text { Brace } \\
\mathbf{5}\end{array}$ & $\begin{array}{c}\text { Brace } \\
\mathbf{2}\end{array}$ & $\begin{array}{c}\text { Brace } \\
\mathbf{1}\end{array}$ & $\begin{array}{c}\text { Brace } \\
\mathbf{4}\end{array}$ & $\begin{array}{c}\text { Brace } \\
\mathbf{6}\end{array}$ \\
\hline 0 & $\mathbf{( M P a )}$ & $\mathbf{( M P a )}$ & $\mathbf{( M P a )}$ & $\mathbf{( M P a )}$ & $\mathbf{( M P a )}$ \\
\hline 22.5 & 1.70 & 4.09 & 2.22 & 2.45 & 7.67 & 2.62 \\
45 & 1.22 & 2.97 & 5.64 & 7.31 & 7.43 & 10.26 \\
67.5 & 0.59 & 3.25 & 8.48 & 10.58 & 4.16 & 13.96 \\
90 & 0.53 & 2.78 & 8.71 & 11.73 & 2.31 & 15.09 \\
112.5 & 0.89 & 1.89 & 7.52 & 10.98 & 1.22 & 12.44 \\
135 & 1.55 & 1.47 & 6.08 & 10.21 & 1.99 & 8.80 \\
157.5 & 3.24 & 2.18 & 4.63 & 6.80 & 3.30 & 5.38 \\
180 & 3.59 & 3.08 & 2.61 & 3.45 & 3.89 & 1.48 \\
202.5 & 1.65 & 2.53 & 3.28 & 7.56 & 4.67 & 5.59 \\
225 & 2.37 & 1.88 & 4.90 & 11.22 & 4.54 & 9.24 \\
247.5 & 1.19 & 2.17 & 8.88 & 12.08 & 5.38 & 12.32 \\
270 & 1.14 & 2.42 & 9.28 & 12.28 & 6.73 & 13.10 \\
292.5 & 1.55 & 2.48 & 7.98 & 10.35 & 5.32 & 15.15 \\
315 & 1.84 & 2.20 & 4.95 & 8.10 & 2.88 & 12.28 \\
337.5 & 2.07 & 2.13 & 3.95 & 4.58 & 3.48 & 8.33 \\
360 & 1.19 & 4.10 & 2.34 & 2.22 & 8.51 & 2.61 \\
\hline & & & & & & \\
\hline
\end{tabular}

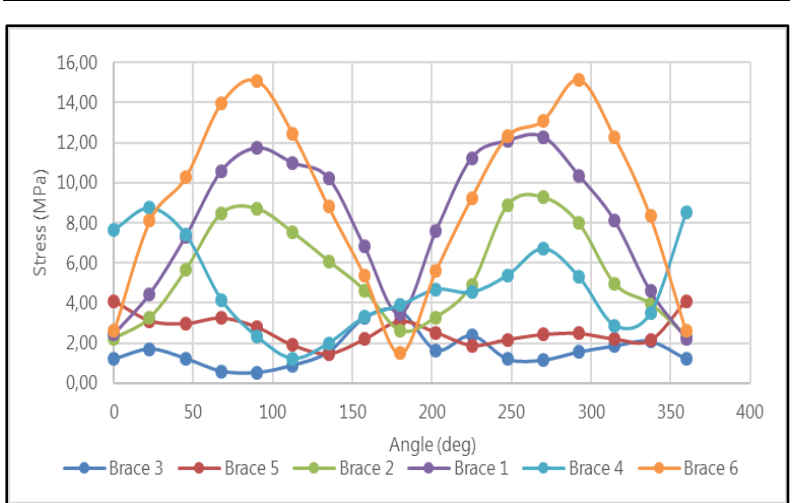

Figure 11. Stress Result Diagram along Weld Toe of The Chord's Side Subjected to In-Plane Bending Moment Loading 
In general, the stress distribution along the weld toe on the chord's side is reaching its peak in two areas, which took place on upper saddle and lower saddle. The hotspot stress is caught occurs at Brace 6 in the upper saddle with magnitude of $15.15 \mathrm{MPa}$. The stress result of the analysis is also taking place along the weld toe of the brace's side as written in Table 7. Additionally, the result from Table $x$ is displayed as a diagram in Figure 12.

Table 7. Stresses Along Weld Toe of The Brace's Side Subjected to In-Plane Bending Moment Loading

\begin{tabular}{ccccccc}
\hline $\begin{array}{c}\text { Angle } \\
\text { (deg) }\end{array}$ & $\begin{array}{c}\text { Brace } \\
\mathbf{3}\end{array}$ & $\begin{array}{c}\text { Brace } \\
\mathbf{5}\end{array}$ & $\begin{array}{c}\text { Brace } \\
\mathbf{2}\end{array}$ & $\begin{array}{c}\text { Brace } \\
\mathbf{1}\end{array}$ & $\begin{array}{c}\text { Brace } \\
\mathbf{4}\end{array}$ & $\begin{array}{c}\text { Brace } \\
\mathbf{6}\end{array}$ \\
\hline 0 & $\mathbf{M P a})$ & $\mathbf{( M P a )}$ & $\mathbf{( M P a )}$ & $\mathbf{( M P a )}$ & $\mathbf{( M P a )}$ \\
22.5 & 1.41 & 4.24 & 2.05 & 1.35 & 4.29 & 1.73 \\
45 & 0.89 & 3.69 & 4.76 & 10.90 & 6.22 & 10.71 \\
67.5 & 0.60 & 3.26 & 6.24 & 12.82 & 4.01 & 15.19 \\
90 & 0.99 & 2.97 & 7.63 & 15.05 & 2.03 & 15.58 \\
112.5 & 1.14 & 1.95 & 6.28 & 14.27 & 1.54 & 8.87 \\
135 & 1.85 & 1.21 & 5.64 & 10.74 & 2.32 & 6.63 \\
157.5 & 4.41 & 1.79 & 4.46 & 7.30 & 2.86 & 2.73 \\
180 & 3.44 & 2.28 & 2.23 & 1.80 & 3.38 & 1.48 \\
202.5 & 1.49 & 2.85 & 3.04 & 7.91 & 4.49 & 3.50 \\
225 & 2.59 & 2.02 & 6.05 & 12.17 & 6.81 & 5.73 \\
247.5 & 1.25 & 2.02 & 11.54 & 13.40 & 7.15 & 9.96 \\
270 & 1.01 & 2.44 & 13.53 & 13.45 & 10.38 & 14.08 \\
292.5 & 1.73 & 2.81 & 10.76 & 11.90 & 6.26 & 16.44 \\
315 & 2.38 & 3.19 & 6.85 & 10.83 & 2.34 & 12.61 \\
337.5 & 2.81 & 3.51 & 2.53 & 5.88 & 2.23 & 6.79 \\
360 & 2.61 & 3.24 & 2.05 & 1.55 & 4.29 & 1.73 \\
\hline & & & & & &
\end{tabular}

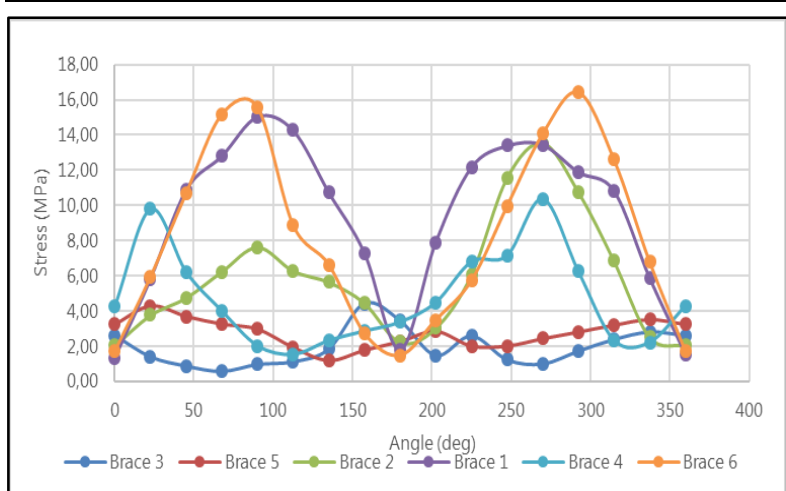

Figure 12. Stress Result Diagram along Weld Toe of The Brace's Side Subjected to In-Plane Bending Moment Loading

While subjected to in-plane bending moment, the stress distribution result along the weld toe on the brace's side is nearly similar with the stress distribution on the chord's side which the maximum stress occurring in two region; upper saddle and lower saddle. Moreover, the hotspot stress occurs in Brace 6 at upper saddle with magnitude of 16.44 $\mathrm{MPa}$. The value of hotspot stress and its occurrence location can be deduced from the above analysis result. The hotspot stress occurs in Brace 6 at upper saddle with a value of $15.15 \mathrm{MPa}$ in the region of the weld toe at the chord's side. Along with that, the hotspot stress occurs in Brace 6 at upper saddle with a magnitude of $16.44 \mathrm{MPa}$ for the region along the weld toe of the brace's side.

\section{Local Stress Analysis Subjected to Out-of-Plane Bending Moment Loading}

The boundary condition used in the analysis is shown in Figure 13. The value of the braces' out-ofplane bending moment is derived from Table 2, and the support at the end of each chord is considered to be fixed. Directions of the out-of-plane bending moment also referring to Table 2 which the positive out-of-plane bending moment is considered in a counter-clockwise direction and the negative outof-plane bending moment is considered in a clockwise direction.

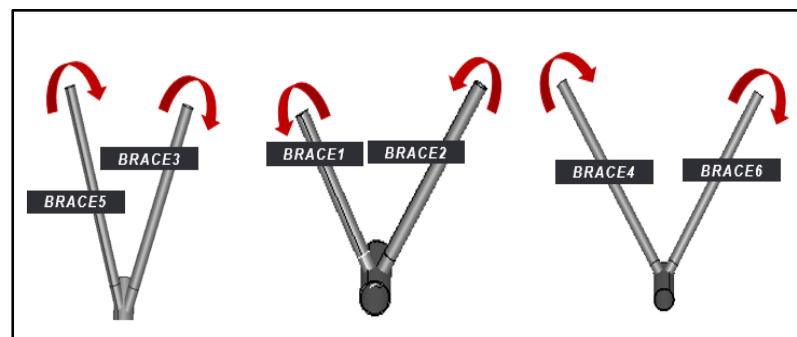

Figure 13. Boundary Condition in the Local Stress Analysis Subjected to Out-of-Plane Bending Moment Loading

After the analysis is conducted, the stress outcome could be obtained. The stress result along the weld toe on the chord's side is shown in Table 8. To obtain the stress distribution along the weld toe an interval of 22.5 degrees is used.

Table 8. Stresses along Weld Toe of The Chord's Side Subjected to Out-of-Plane Bending Moment Loading

\begin{tabular}{ccccccc}
\hline $\begin{array}{c}\text { Angle } \\
(\mathbf{d e g})\end{array}$ & $\begin{array}{c}\text { Brace } \\
\mathbf{3}\end{array}$ & $\begin{array}{c}\text { Brace } \\
\mathbf{5}\end{array}$ & $\begin{array}{c}\text { Brace } \\
\mathbf{2}\end{array}$ & $\begin{array}{c}\text { Brace } \\
\mathbf{1}\end{array}$ & $\begin{array}{c}\text { Brace } \\
\mathbf{4}\end{array}$ & $\begin{array}{c}\text { Brace } \\
\mathbf{6}\end{array}$ \\
\hline 0 & 1.99 & 0.44 & 0.52 & 0.63 & 6.73 & 1.19 \\
22.5 & 2.56 & 0.39 & 0.39 & 0.90 & 6.18 & 1.30 \\
45 & 2.17 & 0.48 & 0.47 & 1.04 & 7.97 & 1.20 \\
67.5 & 1.47 & 0.70 & 0.91 & 1.14 & 4.19 & 1.32 \\
90 & 1.02 & 0.99 & 1.60 & 1.00 & 1.44 & 1.70 \\
112.5 & 0.74 & 1.14 & 1.78 & 0.62 & 1.85 & 1.65 \\
\hline
\end{tabular}




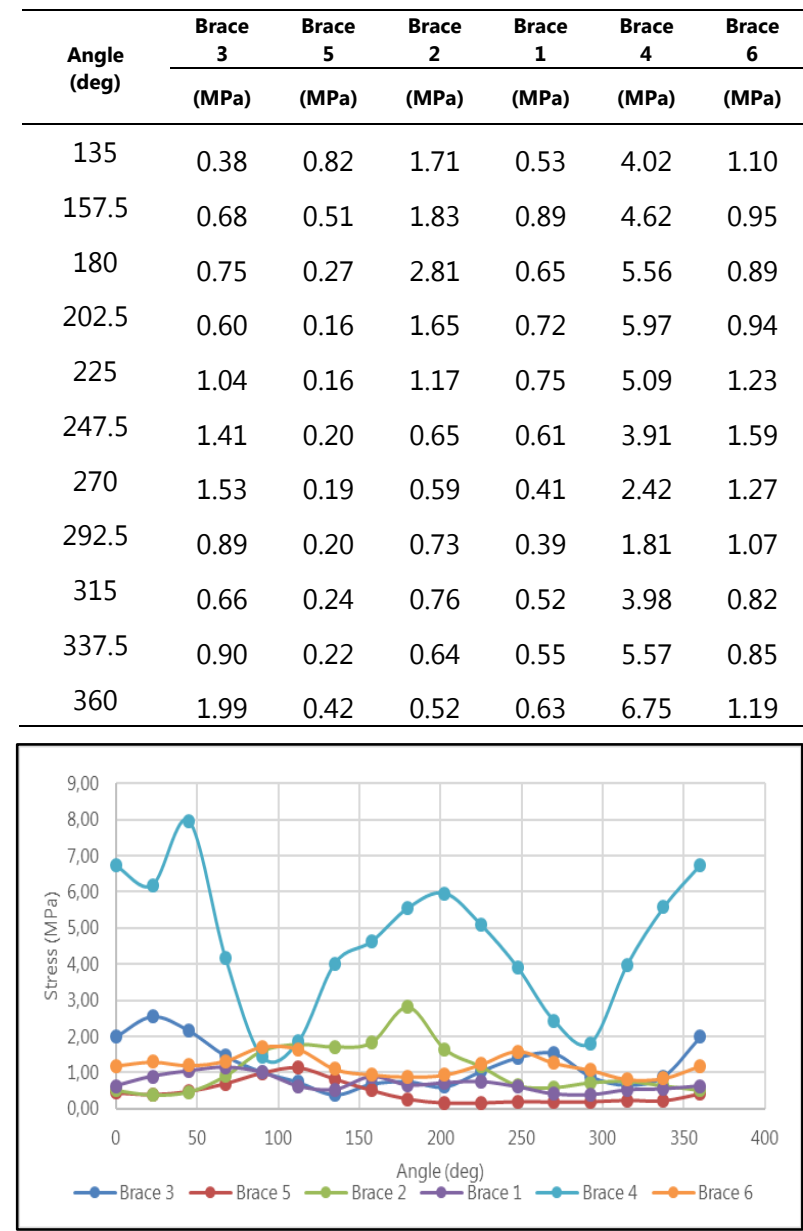

Figure 14. Stress Result Diagram along Weld Toe of The Chord's Side Subjected to Out-of-Plane Bending Moment Loading

Figure 14 shows that stresses along the weld toe is at its maximum value at the crown heel and crown toe. Subsequently, the minimum stresses also occurring in two regions, which are upper saddle and lower saddle region. The hotspot stress is occurring in Brace 4 at crown heel with the magnitude of $7.97 \mathrm{MPa}$. The stress result of the analysis is also taking place along the weld toe of the brace's side as written in

Table 9. Additionally, the result from Table $\mathrm{x}$ is displayed as a diagram in Figure 15.

Table 9. Stresses along Weld Toe of The Brace's Side Subjected to Out-of-Plane Bending Moment Loading

\begin{tabular}{ccccccc}
\hline $\begin{array}{c}\text { Angle } \\
\text { (deg) }\end{array}$ & $\begin{array}{c}\text { Brace } \\
\mathbf{3}\end{array}$ & $\begin{array}{c}\text { Brace } \\
\mathbf{5}\end{array}$ & $\begin{array}{c}\text { Brace } \\
\mathbf{2}\end{array}$ & $\begin{array}{c}\text { Brace } \\
\mathbf{1}\end{array}$ & $\begin{array}{c}\text { Brace } \\
\mathbf{4}\end{array}$ & $\begin{array}{c}\text { Brace } \\
\mathbf{6}\end{array}$ \\
\hline 0 & $\mathbf{M P a})$ & $\mathbf{( M P a )}$ & $\mathbf{( M P a )}$ & $\mathbf{( M P a )}$ & $\mathbf{( M P a )}$ & $\mathbf{( M P a )}$ \\
\hline 2.51 & 0.35 & 0.51 & 0.92 & 6.42 & 0.86 \\
45 & 2.49 & 0.12 & 0.52 & 0.99 & 8.31 & 1.00 \\
45 & 1.75 & 0.11 & 0.33 & 0.98 & 6.49 & 0.93 \\
67.5 & 1.07 & 0.26 & 0.40 & 0.79 & 4.70 & 1.49 \\
90 & 0.85 & 0.37 & 0.99 & 0.74 & 0.95 & 0.95 \\
\hline
\end{tabular}

\begin{tabular}{ccccccc}
\hline $\begin{array}{c}\text { Angle } \\
\text { (deg) }\end{array}$ & \begin{tabular}{c} 
Brace \\
\cline { 2 - 7 }
\end{tabular} & $\begin{array}{c}\text { Brace } \\
\mathbf{5}\end{array}$ & $\begin{array}{c}\text { Brace } \\
\mathbf{2}\end{array}$ & $\begin{array}{c}\text { Brace } \\
\mathbf{1}\end{array}$ & $\begin{array}{c}\text { Brace } \\
\mathbf{4}\end{array}$ & $\begin{array}{c}\text { Brace } \\
\mathbf{6}\end{array}$ \\
\hline 112.5 & 0.59 & 0.63 & 1.13 & 0.59 & 2.88 & 0.96 \\
135 & 0.35 & 0.71 & 1.39 & 0.80 & 3.72 & 0.68 \\
157.5 & 0.82 & 0.54 & 1.86 & 1.34 & 4.56 & 0.66 \\
180 & 0.75 & 0.33 & 1.74 & 1.04 & 5.34 & 0.59 \\
202.5 & 0.52 & 0.20 & 1.37 & 0.59 & 5.30 & 0.58 \\
225 & 1.13 & 0.17 & 1.15 & 0.59 & 4.63 & 0.51 \\
247.5 & 1.39 & 0.15 & 0.66 & 0.57 & 3.50 & 0.78 \\
270 & 0.98 & 0.14 & 0.35 & 0.50 & 1.90 & 1.08 \\
292.5 & 0.64 & 0.14 & 0.32 & 0.59 & 2.18 & 1.16 \\
315 & 0.71 & 0.07 & 0.60 & 0.82 & 3.65 & 0.68 \\
337.5 & 1.17 & 0.21 & 0.57 & 0.83 & 4.12 & 0.63 \\
360 & 2.51 & 0.35 & 0.51 & 0.86 & 7.10 & 0.86 \\
\hline
\end{tabular}

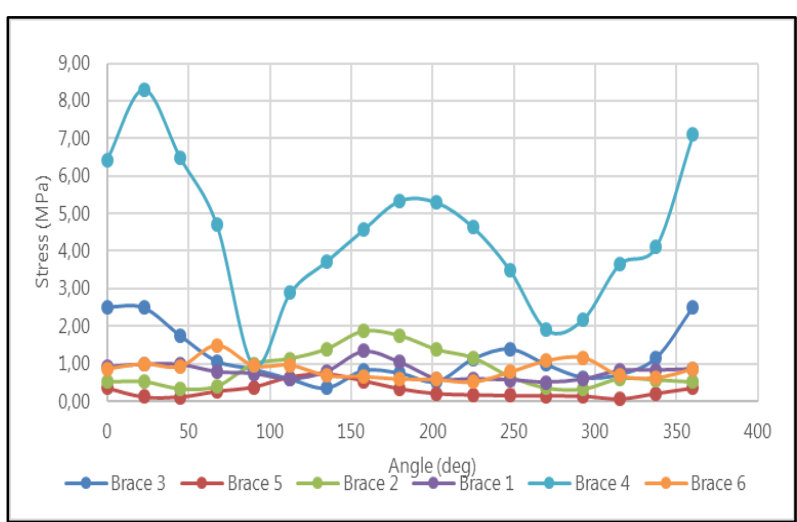

Figure 15. Stress Result Diagram along Weld Toe of The Brace's Side Subjected to Out-of-Plane Bending Moment Loading

Figure 15 illustrates that at the crown heel and crown toe, stresses along the weld toe are at their highest. As a result, the minimum stresses occur in two regions; the upper saddle and the lower saddle region. With a magnitude of $8.31 \mathrm{MPa}$, the hotspot stress occurs in Brace 4 at the crown heel. The analysis result above is used to assess the amount of hotspot stress and its occurrence position. In the area of the weld toe on the chord's edge, the hotspot stress arises in Brace 4 at crown heel with a value of $7.97 \mathrm{MPa}$. Besides, the hotspot stress for the area along the weld toe of the brace's side also arises in Brace 4 at crown heel with a magnitude of 8.31 MPa.

In conclusion towards the entire conducted analysis, it could be concluded that the loading type of axial force has the biggest impact concerning to the stress output. As the comparison, the hotspot stress on the weld toe at the chord's side is 1.9 times 
higher than hotspot stress from in-plane bending moment loading and 3.625 times higher that hotspot stress from out-of-plane bending moment loading.

\section{CONCLUSIONS}

Through all the analysis that has been conducted, it is possible to draw a conclusion as follows. 1) The hotspot stress subjected to axial force loading occurs in brace 3 at the crown toe with the value of $29 \mathrm{MPa}$ for the chord's side of the weld toe and $27 \mathrm{MPa}$ for the brace's side of the weld toe. 2) Brace 3 is alleged as the occurrence spot of hotspot stress with the value of $15 \mathrm{MPa}$ in the weld toe on the chord's side and $16 \mathrm{MPa}$ in the weld toe on the brace's side when subjected to the in-plane bending moment loading. 3) As for the out-ofplane bending moment loading. the hotspot stress arises in brace 4 with the magnitude of $8 \mathrm{MPa}$ in the chord's side of the weld toe and $8.3 \mathrm{MPa}$ in the brace's side of the weld toe. 4) The axial force is the loading type that has the greatest impact on the hotspot stress which $1.9^{*}\left(1.6^{* *}\right)$ times higher than the hotspot stress which caused by in-plane bending moment and $3.6^{*}\left(3.3^{* *}\right)$ times higher than the hotspot stress obtained from the out-of-plane bending moment loading.

\section{REFERENCES}

Ahmadi, H., \& Ziaei Nejad, A. (2017). Geometrical effects on the local joint flexibility of two-planar tubular DK-joints in jacket substructure of offshore wind turbines under OPB loading. ThinWalled Structures, 114(February), 122-133. https://doi.org/10.1016/j.tws.2017.02.001

API. (2007). Recommended Practice for Planning Designing and Constructing Fixed Offshore Platforms - Working Stress Design. Api Recommended Practice, 24-WSD(December 2000),

http://scholar.google.com/scholar?hl=en\&btnG $=$ Search\&q=intitle:Recommended + Practice + fo $r+$ planning, +designing + and +constructing + fixe $\mathrm{d}+$ Offshore+Platforms +-

+ Working +stress+design\#0

Aubry, J. (2013). Jean-Pierre Aubry Beginning with code_aster. Framasoft. http://framabook.org.

AWS. (1981). Structural Welding Code - Steel. In American National Standards Institute, Standards
(Vol. 552, Issue 20).

Chandran, A., \& S, A. (2016). Static Strength Analysis of a Tubular K- Joint of an Offshore Jacket Structure. International Journal of Science and Research (IJSR), 5(7), 708-713. https://www.ijsr.net/archive/v5i7/NOV163516.p df

Giffary, M. N. (2020). Fatigue Life Comparison of Modified Conventional 3 Legged Jacket Structure. In Departemen Teknik Kelautan.

Mirtaheri, M., Zakeri, H. A., Alanjari, P., \& Assareh, M. A. (2009). Effect of Joint Flexibility on Overall Behavior of Jacket Type Offshore Platforms. American Journal of Engineering and Applied Sciences, 2(1), 25-30. https://doi.org/10.3844/ajeassp.2009.25.30

Nicholson, G., \& Helle, Y. (2013). Modular design for low cost minimum facilities platforms. SPE Middle East Oil and Gas Show and Conference, MEOS, Proceedings, 2, 1365-1377. https://doi.org/10.2118/164325-ms

Prastianto, R., Hadiwidodo, Y., Widhestomo, S., \& Yazhahir, R. (2020). Stress Distribution along the Weld Toes of Tubular KT and KDT Joints under Balance Axial Loads and In-Plane-Bending Moments. Isoceen 2018, 170-175. https://doi.org/10.5220/0008650101700175

Prastianto, R. W., Hadiwidodo, Y. S., \& Fuadi, I. F. (2018). Stress concentration factor of a twoplanar double KT tubular joint due to in-plane bending loading in steel offshore structures. MATEC Web of Conferences, 177. https://doi.org/10.1051/matecconf/2018177010 06

Prastianto, R. W., Hadiwidodo, Y. S., Fuadi, I. F., Prawira Naibaho, M. B. Y., \& Rahardianto, P. N. (2018). Stress concentration factor distribution of inclined brace in multiplanar offshore tubular double kt joints. IOP Conference Series: Earth and Environmental Science, 162(1). https://doi.org/10.1088/17551315/162/1/012049

Sellenet, N. (2016). Operator CALC_CHAMP CodeAster. Electricite de France.

SKK Migas. (2019). Laporan Tahunan 2019 SKK Migas (Issue 1). 